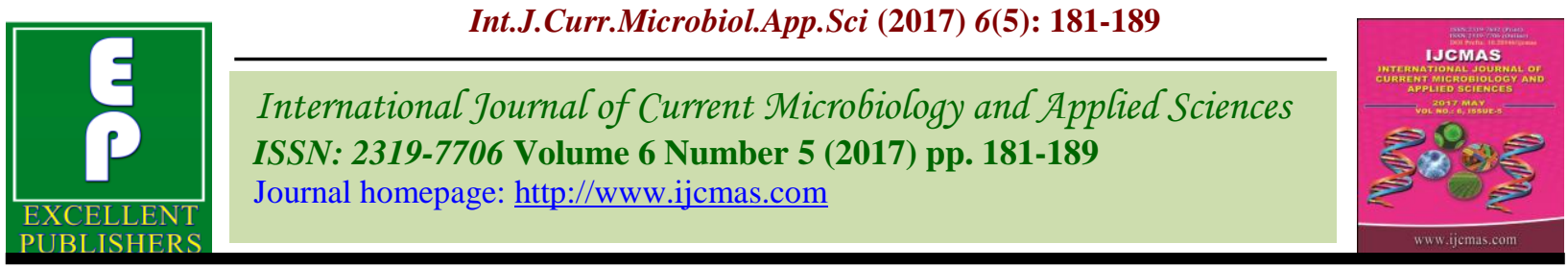

Original Research Article

https://doi.org/10.20546/ijcmas.2017.605.021

\title{
Genetic Divergence in Wheat (Triticum aestivum L.Thell.) Under Saline Sodic Condition
}

\author{
Manoj Kumar Pandey*, H.N. Bind, Sanjeev Kumar and B.N. Singh \\ Department of Genetics and Plant Breeding, ND University of Agriculture and Technology \\ Kumarganj, Faizabad-224229 (UP) India \\ *Corresponding author
}

\section{A B S T R A C T}

\section{Keywords}

Divergence,

Euclidean cluster, Grain yield, Wheat.

Article Info

Accepted:

04 April 2017

Available Online:

10 May 2017

\begin{abstract}
Recently, abiotic stress like salinity, drought and temperature are the severe problems to worldwide wheat production, mostly in arid and semiarid areas. A feasible solution is breeding for salt-tolerant cultivars of wheat, while the presence of genetic variation is a prerequisite for genetic improvement. In the present investigation, an experiment was conducted to estimate the nature and magnitude of genetic diversity in improved varieties of bread wheat during Rabi, 2010-11. Total number of 143 exotic and indigenous lines of bread wheat including three checks was apprised in partially reclaimed salt affected soil under late sown and irrigated conditions. The experiment was conducted in Augmented Block Design having 7 blocks of 23 plots each, at Narendra Deva University of Agriculture and Technology, Narendra Nagar (Kumarganj), Faizabad. All the wheat germplam were grouped into twelve clusters by estimating genetic divergence of eleven quantitative traits using the non-hierarchical Euclidean cluster analysis which showed the highest inter-cluster distance between cluster VI and cluster XII. The genotypes having high mean performance for grain yield per plant and several other yield components were found to be concentrated in cluster IV and VI which merit showed due consideration for selection of parents. Thus, crosses between promising lines belonging to cluster pair having higher inter-cluster distances may be attempted for isolating transgressive segregants as these cluster pair were also separated by high inter-cluster distances. The twelve clusters formed in divergence analysis contained genotypes of heterogeneous origin, thereby indicating non-parallelism between genetic and geographic diversity. Therefore, crosses between the members of clusters separated by high inter-cluster distances are likely to throw desirable segregates. This indicated existence of high degree of genetic diversity in the wheat exotic and indigenous lines. Therefore, these exotic and indigenous lines may serve as valuable source for selecting diverse parents for use in hybridization programme.
\end{abstract}

\section{Introduction}

Wheat (Triticum aestivum L. em. Thell.) is a major staple food in the world after rice and primarily grown in tropical-temperate region worldwide due to wide high adaptation and greater role in human nutrition as well as in agricultural economy. Abiotic stress factors such as cold, frost, drought, salinity, severely limit plant growth and development as well as the adaptability and mechanisms of plant growth reducing yield in crops including 
cereals from the tribe Triticeae (Wang et al., 2003, Kosová et al., 2014).

Salinity is the major threat to global wheat production and effect about $6 \%$ of the world's area, particularly in arid and semiarid areas of the world. Even in irrigated areas, salt concentration increases in the subsoil due to evaporation of water with the passage of time. Saline soils have soluble salts responsible for reducing economic importance and yield of crop (Munns and James, 2003). Such a large salt-affected area and economical loss is major problems for farmers facing a decline in their income that poses a threat to national and international food security. Possible solutions include increasing the area under wheat cultivation and developing superior varieties that provide a good yield under saline condition. In arid and semiarid areas, yield can be increased significantly by developing salt-tolerant crop varieties (Clark and Duncan, 1993) by exploiting genetic diversity for salt tolerance in species and developing screening techniques.

New genetic sources require developing tolerance to salinity in crops under various breeding programs. Hence, salt tolerant cultivars/genotypes of wheat should be needed to sustain for high yield production under salinity condition (Munns, 2005). Diversity can ensure sustainability and improvement in the livelihoods of farmers in unfavorable environmental conditions providing high yielding crop varieties with important useful traits.

Selection and hybridizations techniques are frequently used for improving genetic constitution of a genotype. Genetic divergence analysis is important tool to estimate genetic diversity among selected genotypes which determine family relationships and genetic affinity or distance of genotypes from each other studying cluster analysis (Mellingers, 1972).
For obtain transgressive segregants, genetic distance between parents is necessary (Joshi et al., 2004) to estimate by Euclidean distance (Hoque and Rahman, 2006). Germplasm improvement and genetic diversity are useful for reliable and sustainable production of the food crops. For effective evaluation and utilization of germplasm, measure of extent of available genetic diversity is of utmost importance (Zubair et al., 2007). The use of multivariate statistical algorithms is an important strategy for classification of germplasm and analysis of genetic relationships among breeding material (Mohammadi and Prasanna, 2003). The aims of the present study are investigation of genetic diversity and identification between selected genotypes and local cultivar of wheat for salt tolerance by cluster distance analysis.

\section{Materials and Methods}

In the present investigation experiment material consisted of 140 exotic and indigenous wheat germplasm lines and three check varieties viz., KRL-210, NW-2036, and NW-1067 with pedigree (Table 1) collected from genetic stock available in Wheat Section, Department of Genetics and Plant Breeding, Narendra Deva University of Agriculture and Technology, Kumarganj, Faizabad. The experiment was carried out in Augmented Block Design in semi-arid region of Faizabad during Rabi 2010-11. The entire experimental field was divided into 7 blocks of equal size and each block having 23 plots. Out of 23 plots in a block, 20 plots were used for accommodating the test genotypes which were not replicated while remaining 3 checks i.e. KRL-210, NW-2036, NW-1067 which were replicated in three rows plot of $3 \mathrm{~m}$ long with inter and intra-row spacing of $25 \mathrm{~cm}$ and $5 \mathrm{~cm}$, respectively. Experimental site was reclaimed salt affected soil having EC 0.39, $\mathrm{pH}>8.5$, ESP $<15$ and rich in potash and low in organic carbon, nitrogen and phosphorus. 
Recommended dose of fertilizers N:P:K @ 150:60:60 and cultural packages were applied to raise a good and healthy crop. The observation were recorded from five randomly selected plants for all the quantitative characters viz., plant height (cm), number of productive tillers plant ${ }^{-1}$, spike length $(\mathrm{cm})$, peduncle length $(\mathrm{cm})$, grains spike $^{-1}$, 1000-grain weight (g), biological yield plant $^{-1}(\mathrm{~g})$, grain yield plant $^{-1}(\mathrm{~g})$, harvest index $(\%)$, flag leaf area $\left(\mathrm{cm}^{2}\right)$ except days to maturity, which was recorded on the plot basis. Cluster analysis was done by using Tocher's method (Rao, 1952) and genetic divergence of the pooled data of all the genotypes analyzed by Mahalanobis (1936) $\mathrm{D}^{2}$ statistics. The genetic divergence among the wheat varieties were calculated by canonical (Vector) and non-hierarchical Euclidean methods of divergence estimation. The D2 values were calculated by using the method described by Mahalanobis (1936). Genetic divergence analysis using canonical (vector) method is a sort of multivariate analysis where canonical vector and roots representing different axes of differentiation and the amount of variation accounted for by each of such axes, respectively, were derived (Rao,1952). Non- hierarchical Euclidean cluster analysis (Beale, 1969; Katyal et al., 1985) was conducted using computer package (Windostat version 8.5).

\section{Results and Discussions}

The non-hierarchical Euclidean cluster analysis was studied to survey the genetic divergence among 143 wheat germplasm on the basis of 11 quantitative characters. The pseudo F-test revealed that 12 nonoverlapping cluster arrangements were the most appropriate for grouping all the genotypes (Table 1). Among the evaluated genotypes in saline sodic condition, the maximum numbers of genotype were grouped in cluster II (21 genotypes) followed by cluster VII (18 genotypes), while minimum numbers of genotype grouped in cluster VI (only 4 genotypes) (Table 2). The highest intra-cluster distance was observed in cluster $\mathrm{V}\left(\mathrm{D}^{2}=81.46\right)$, followed by cluster VI $\left(\mathrm{D}^{2}=\right.$ 78.77) (Table 2). The lowest intra-cluster value was recorded for cluster $X\left(D^{2}=43.93\right)$, followed by cluster VII $\left(\mathrm{D}^{2}=44.38\right)$. Zaman et al., (2005) observed diversity with high range of values of inter and intra cluster distance among wheat genotypes under Inter cluster distance is important to screen genotypes using $\mathrm{D}^{2}$ analysis Singh et al., (2013). Genotypes belonging to those clusters showing higher inter cluster distance considered genetically more divergent and hybridization between these genotypes of dissimilar clusters is likely to generate broad variability with desirable sergeants Gartnar et al., (1989) and Singh et al., (2006). The analysis of variance exhibited significant variation among the genotypes for all the quantitative characters.

The maximum generalized inter cluster distance $\left(D^{2}\right)$ was recorded between cluster VI and XII $\left(\mathrm{D}^{2}=1495.20\right)$, followed by cluster VI and VII $\left(\mathrm{D}^{2}=1017.754\right)$. Thus, hybridization between genotypes from these clusters may result in maximum hybrid vigour and highest number of useful segregates Shwi et al., (1972).The minimum inter-cluster distance was found between cluster VII and VIII $\left(D^{2}=74.95\right)$ followed by cluster VII and IX $\left(D^{2}=76.50\right)$ indicating that the genotypes in these two clusters were relatively close to each other.

On the basis of average cluster mean values (Table 3) for 11 characters, the genotype of cluster IV showed maximum divergence for peduncle length (31.293), spike length (10.948), grains per spike (41.489), biological yield per plant (23.214) and grain yield per plant (8.736). 
Table.1 Clustering pattern of 140 wheat genotypes on the basis of non-hierarchical Euclidean cluster analysis of 11 characters

\begin{tabular}{|c|c|c|}
\hline $\begin{array}{l}\text { Cluster } \\
\text { No. }\end{array}$ & $\begin{array}{l}\text { No. of } \\
\text { genotypes }\end{array}$ & Name of genotypes \\
\hline I & 15 & 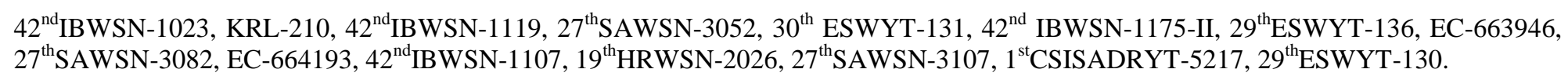 \\
\hline II & 21 & 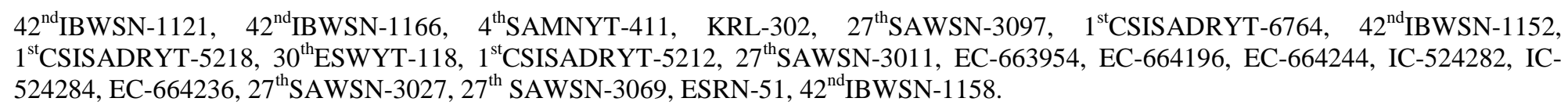 \\
\hline III & 14 & $\begin{array}{l}42^{\text {nd }} \text { IBWSN- 1113, EC-634300-88, KRL-301, KRL-312, } 10^{\text {th }} \text { EGPYT-7, KRL-315, } 1^{\text {st }} \text { CSISADRYT-6767, EC-664009, } 1{ }^{\text {st }} \text { SATYN-60, IC- } \\
553917,1^{\text {st }} \text { SATYN-26, EC-663961, KRL-306, } 10^{\text {th }} \text { DSBWYT-407. }\end{array}$ \\
\hline IV & 12 & $\begin{array}{l}42^{\text {nd }} \text { IBWSN- } 1151, \text { EC-634300-106, EC-634300-103, EC-634300-81, } 1^{\text {st }} \text { SATYN-45, } 42^{\text {nd }} \text { IBWSN }-1150,42^{\text {nd }} \text { IBWSN-1038-II, } 42^{\text {nd }} \\
\text { IBWSN-1057, } 1^{\text {st }} \text { SATYN-37, } 1^{\text {st }} \text { SATYN-35, } 1^{\text {st }} \text { SATYN-38, IC-546933. }\end{array}$ \\
\hline $\mathrm{V}$ & 6 & $42^{\text {nd }}$ IBWSN- $1173,10^{\text {th }}$ EGPYT- $11,1^{\text {st }}$ SATYN-46, $1^{\text {st }}$ SATYN-53, $10^{\text {th }}$ DSBWYT-420, 42 ${ }^{\text {nd }}$ IBWSN 1175-I. \\
\hline VI & 4 & EC-634300-69, EC-634300-99, EC-634300-64, EC-634300-110. \\
\hline VII & 18 & $\begin{array}{l}42^{\text {nd }} I B W S N-1034,16^{\text {th }} \text { HRWYT-206, EC-664229, } 4^{\text {th }} \text { EBWYT-511, EC-664208, EC-664200, } 42^{\text {nd }} I B W S N-1112,27^{\text {th }} \text { SAWSN-3004, } \\
42^{\text {nd }} I B W S N-1038-I, 42^{\text {nd }} I B W S N-1170 \text {, ESRN-11, NW-1067, 42 }{ }^{2 n} I B W S N-1039, \text { EC-634300-76,GW-2008-156,GW-2007-87,GW-2007-92, } \\
\text { EC-664189. }\end{array}$ \\
\hline VIII & 8 & $29^{\text {th }}$ ESWYT-110, EC-634300-95, RAJ-4211, NW-5029, GW-2008-157, NW-2036, 42 ${ }^{\text {nd }}$ IBWSN-1087, EC-664215. \\
\hline IX & 10 & IC-524288, WH-1083, ESRN-15, KRL-307, KRL-322, ESRN-3, $10^{\text {th }}$ DSBWYT-422, KRL-305, KRL-299, GW-2008-153. \\
\hline $\mathrm{X}$ & 9 & $\begin{array}{l}42^{\text {nd }} I B W S N-1164, K R L-309, \text { EC-634300-82, KRL-323, 42 } 2^{\text {nd }} I B W S N-1146,42^{\text {nd }} I B W S N-1167,42^{\text {nd }} I B W S N-1169,12^{\text {th }} \text { EGPSN-51, } 42^{\text {nd }} \\
\text { IBWSN-1065. }\end{array}$ \\
\hline XI & 11 & $\begin{array}{l}30^{\text {th }} \text { ESWYT-119, } 42^{\text {nd }} I B W S N-1021,1^{\text {st }} \text { SATYN-23, WH-1097, } 4^{\text {th }} \text { EBWYT-509, KRL-300, IC-549914, EC-414149, KRL-303, KRL-304, } \\
42^{\text {nd }} \text { IBWSN-1137. }\end{array}$ \\
\hline XII & 15 & $\begin{array}{l}42^{\text {nd }} \text { IBWSN-1063, KRL-324, EC-664199, 42 }{ }^{\text {nd }} \text { IBWSN -1103, EC-634300-133, EC-664227, LBP-2009-24, KRL-316, GW-2008-159, GW- } \\
\text { 2006-17, GW-2007-96, EC-634300-94, EC-634300-63, RWP-2009-12, GW-2007-80. }\end{array}$ \\
\hline
\end{tabular}


Table.2 Estimates of average intra and inter- cluster distances for 12 clusters in exotic and indigenous lines of wheat

\begin{tabular}{|c|c|c|c|c|c|c|c|c|c|c|c|c|}
\hline Cluster no. & $\mathrm{I}$ & II & III & IV & $\mathrm{V}$ & VI & VII & VIII & IX & $\mathrm{X}$ & XI & XII \\
\hline I & 50.459 & 107.919 & 207.148 & 184.839 & 417.185 & 783.524 & 143.680 & 81.681 & 199.293 & 99.952 & 200.399 & 245.049 \\
\hline II & & 64.726 & 129.939 & 127.409 & 203.186 & 475.977 & 221.040 & 153.341 & 207.827 & 136.471 & 261.090 & 405.992 \\
\hline III & & & 61.992 & 84.273 & 193.024 & 492.581 & 174.211 & 180.486 & 113.419 & 141.786 & 166.004 & 381.173 \\
\hline IV & & & & 51.732 & 210.339 & 440.298 & 205.062 & 207.749 & 176.660 & 111.925 & 153.766 & 442.735 \\
\hline $\mathrm{V}$ & & & & & 81.46 & 188.211 & 534.267 & 472.904 & 405.757 & 377.517 & 519.219 & 858.093 \\
\hline VI & & & & & & 78.769 & 1017.754 & 921.181 & 874.149 & 756.484 & 944.062 & 1495.208 \\
\hline VII & & & & & & & 44.381 & 74.957 & 76.500 & 110.332 & 82.788 & 109.961 \\
\hline VIII & & & & & & & & 46.170 & 110.919 & 119.362 & 147.435 & 136.426 \\
\hline IX & & & & & & & & & 49.220 & 131.383 & 104.060 & 173.591 \\
\hline$X$ & & & & & & & & & & 43.928 & 97.459 & 240.134 \\
\hline XI & & & & & & & & & & & 53.777 & 199.403 \\
\hline XII & & & & & & & & & & & & 67.654 \\
\hline
\end{tabular}

Bold figures indicate intra-cluster distances.

Table.3 Cluster means for different characters in exotic and indigenous lines of wheat

\begin{tabular}{|c|c|c|c|c|c|c|c|c|c|c|c|}
\hline $\begin{array}{l}\text { Cluster } \\
\text { number }\end{array}$ & $\begin{array}{l}\text { Flag leaf } \\
\text { area }\left(\mathrm{cm}^{2}\right)\end{array}$ & $\begin{array}{l}\text { Days to } \\
\text { maturity }\end{array}$ & $\begin{array}{c}\text { Peduncle } \\
\text { length }(\mathrm{cm})\end{array}$ & $\begin{array}{l}\text { Plant height } \\
\text { (cm) }\end{array}$ & $\begin{array}{l}\text { Spike length } \\
\text { (cm) }\end{array}$ & $\begin{array}{c}\text { Grains } \\
\text { per spike }\end{array}$ & $\begin{array}{c}\text { Reproductive } \\
\text { tillers per } \\
\text { plant }\end{array}$ & $\begin{array}{l}1000 \text { grain } \\
\text { weight }(\mathrm{g})\end{array}$ & $\begin{array}{l}\text { Biological } \\
\text { yield per } \\
\text { plant(g) }\end{array}$ & $\begin{array}{l}\text { Grain yield } \\
\text { per plant }(g)\end{array}$ & $\begin{array}{l}\text { Harvest } \\
\text { index }(\%)\end{array}$ \\
\hline I & 19.723 & 125.400 & 29.226 & 81.493 & 10.398 & 40.629 & 4.879 & 39.343 & 20.484 & 7.823 & 38.117 \\
\hline II & 18.570 & 124.952 & 29.548 & 82.694 & 9.950 & 38.673 & 4.879 & 39.770 & 19.982 & 7.591 & 37.892 \\
\hline III & 19.391 & 124.357 & 27.720 & 79.753 & 9.883 & 39.494 & 5.118 & 40.336 & 21.038 & 8.155 & 38.779 \\
\hline IV & 20.352 & 123.833 & 31.293 & 85.035 & 10.948 & 41.489 & 5.282 & 39.565 & 23.214 & 8.736 & 37.587 \\
\hline V & 18.885 & 125.500 & 30.250 & 80.848 & 9.418 & 38.660 & 4.817 & 40.107 & 19.345 & 7.427 & 38.590 \\
\hline VI & 20.550 & 125.250 & 26.425 & 76.200 & 9.605 & 39.323 & 5.525 & 40.520 & 22.860 & 8.705 & 38.033 \\
\hline VII & 21.525 & 124.000 & 30.061 & 81.853 & 9.924 & 39.564 & 4.568 & 39.589 & 18.987 & 7.161 & 37.817 \\
\hline VIII & 22.334 & 124.375 & 30.425 & 85.563 & 9.628 & 38.520 & 4.940 & 39.112 & 19.336 & 7.454 & 38.425 \\
\hline IX & 18.616 & 124.900 & 28.510 & 80.814 & 10.201 & 40.225 & 5.140 & 39.453 & 20.514 & 8.121 & 39.568 \\
\hline $\mathrm{X}$ & 22.662 & 125.444 & 30.183 & 84.429 & 10.469 & 40.177 & 4.827 & 41.013 & 21.208 & 8.150 & 38.433 \\
\hline XI & 19.618 & 125.455 & 29.755 & 81.753 & 10.422 & 40.440 & 4.785 & 41.079 & 20.706 & 7.916 & 38.299 \\
\hline XII & 18.699 & 123.733 & 30.127 & 81.390 & 9.403 & 38.449 & 4.736 & 39.699 & 18.912 & 7.255 & 38.429 \\
\hline
\end{tabular}


Table.4 Diverse and superior genotypes with desirable traits selected from different clusters

\begin{tabular}{|c|c|c|}
\hline $\mathrm{SN}$ & Characters & Genotypes \\
\hline 1. & Flag leaf area $\left(\mathrm{cm}^{2}\right)$ & $\begin{array}{l}\text { GW 2007-80, ESWYT-110, KRL-315, GW 2008-153, 1CSISADRYT-5217, RWP 2009-12, IBWSN-175, } \\
\text { 1SATYN-53, IBWSN-34, IC-524284 }\end{array}$ \\
\hline 2. & Days to maturity (Early)type & $\begin{array}{l}\text { IC-546933, GW 2008-157, GW 2008-156, EC-634300-99, GW 2007-92, KRL-315, EC-634300-64, IC- } \\
\text { 549914, IC-524288, EC-664236, EC-634300-110 }\end{array}$ \\
\hline 3. & Peduncle length (cm) & $\begin{array}{l}\text { IBWSN-103, IBWSN-63, EC-634300-63, 43IBWSN-1107, EC-664199, EC-664189, EC-634300-133, EC- } \\
\text { 634300-95., ESWYT-110, IBWSN-137, IBWSN-112 }\end{array}$ \\
\hline 4. & Plant height (cm) (Dwarf) & $\begin{array}{l}\text { EC-634300-133, EC-634300-94, IBWSN-103, IBWSN-63, GW 2006-17, RWP 2009-12, KRL-324, GW } \\
\text { 2008-159, GW 2007-96., LBP 2009-24, EC-634300-63 }\end{array}$ \\
\hline 5. & Spike length $(\mathrm{cm})$ & $\begin{array}{l}\text { 10EGPYT-11, EC-664236, GW 2008-153, 10DSBWYT-420, 27SAWSN-3027, ESRN-51, 27SAWSN-3069, } \\
\text { EC-663954, EC-634300-110, EC-664244, EC-664215 }\end{array}$ \\
\hline 6. & Grains per spike & $\begin{array}{l}\text { 27SAWSN-3027, 27SAWSN-3069, ESRN-51, EC-664236, EC-634300-63, EC-664196, 10DSBWYT-420, } \\
\text { GW 2008-153 }\end{array}$ \\
\hline 7. & Reproductive tillers per plant & $\begin{array}{l}\text { IC-524282, GW 2008-157, 29ESWYT-130, IC-524284, 43IBWSN-1107, EC-664236, 29ESWYT-136, IC- } \\
\text { 553917, EC-634300-110, EW-EC-664215, NW-5029 }\end{array}$ \\
\hline 8. & 1000- grain weight $(\mathrm{g})$ & $\begin{array}{l}\text { 45IBWSN-1175, 1CSISADRYT-5218, IBWSN-152, ESRN-51, 27SAWSN-3107, 30ESWYT-131, KRL-323, } \\
\text { 43IBWSN-1107, 29ESWYT-130 }\end{array}$ \\
\hline 9. & Biological yield per plant (g) & $\begin{array}{l}\text { EC-664236, EC-634300-110, 29ESWYT-130, IC-524282, IBWSN-158, 27SAWSN-3107, 1CSISADRYT- } \\
\text { 5217, EC-664244, EC-663946, EC-664215 }\end{array}$ \\
\hline 10. & Harvest index (\%) & $\begin{array}{l}\text { KRL-306, EC-663961, 1SATYN-46, GW 2007-80, 1SATYN-60, 29ESWYT-130, 1SATYN-26 EC-634300- } \\
\text { 94, NW-5029, EC-634300-76 }\end{array}$ \\
\hline 11. & Grain yield plant $^{-1}(\mathrm{~g})$ & $\begin{array}{l}\text { 29ESWYT-130, IBWSN-158, 27SAWSN-3107, EC-664236, EC-634300-110, IC-524282, 19HRWSN-2026, } \\
\text { 1CSISADRYT-5217, } 43 \text { IBWSN-1107, } 27 \text { SAWSN-3027 }\end{array}$ \\
\hline
\end{tabular}


Others traits viz., flag leaf area (22.662), days to maturity (125.500), plant height (85.563), reproductive tillers per plant (5.525), 1000 grain weight (41.079) and harvest index (39.568) exhibited maximum cluster mean in the cluster X, V, VIII, VI, XI and IX, respectively. Whereas, cluster XII, contained four traits and cluster VI and VII bear two trait, which exhibited minimum cluster mean values and cluster II, IV, VIII, consisted of only one trait which exhibited minimum cluster mean values. These results are in conformity with those obtained by Hailegiorgis et al., (2011) for grain yield. Based on cluster means, cluster IV has been identified for selecting parents for incorporating peduncle length, spike length, grains per spike, biological yield per plant and grain yield per plant. Similar grouping of genotypes has also been reported by Bergale et al., (2001). The present study confirms the findings of Verma et al., (2014), who grouped 108 wheat genotypes into eleven clusters based on their various morpho-agronomic traits. The identified genotypes superior in the above cluster may be involved in a multiple crossing programmes to recover transgressive segregants with high genetic yield potential. Evaluation of genetic diversity can be useful for the selection of the most efficient genotypes (Table 4). Accordingly, if such efforts result in the reduction of diversity, production of plants with higher uniformity may guarantee the production of enough food for the world increasing population.

The grouping of genotypes reveled that indentified tolerant genotypes may be used as donor in various hybridization programmes to improve yield under sodic soil created saline stress environment. Earlier studied have also reported substantial genetic divergence in wheat (Deshmukh et al., 1999; Roy et al., 2004; Verma et al., 2006; Singh et al., 2006; Iqubal et al., 2007). The grouping of genotypes reveled that indentified tolerant genotypes may be used as donor in various hybridization programmes to improve yield under sodic soil created saline stress environment. Earlier studied have also reported substantial genetic divergence in wheat (Deshmukh et al., 1999; Roy et al., 2004; Verma et al., 2006; Singh et al., 2006; Iqubal et al., 2007). The cluster pattern of the genotypes showed non-parallelism between geographic and genetic diversity (Singh et al., 2009). The statistical analysis revealed that the diverse clusters showed high inter cluster distances which might generate a wide range of transgressive segregants for development of high yielding wheat varieties (Kumar et al., 2015). High degree of genetic divergence observed in the present study on the analysis of all the wheat genotypes.

In conclusion the existence of considerable significant genetic variations was acquired among the genotypes for all the eleven selected quantitative characters under sodic soil condition, which may help for further selection and breeding. Identified superior genotypes may be selected from those clusters which had significant genetic distance for crossing in order to obtain genetic recombination and transgressive segregation in the subsequent generations. Results are important to contrast to the sodic soil conditions will assist breeding programs to identify tolerant genotypes under sodic soil conditions.

\section{References}

Beale, E.M.L. 1969. Euclidean cluster analysis, A paper contributed to 37th session of the Indian National Statistical Institute.

Bergale, S., Billore, M., Holkar, A.S., Ruwali, K.N., Prasad, S.V.S. and Mridulla, B. 2001. Genetic variability, diversity and association of quantitative traits with grain yield in bread wheat (Triticum 
aestivum L.). Madras Agri. J., 88(7-9): 457-461.

Clark, R.B. and R.R. Duncan. 1993. Selection of plants to tolerate soil salinity, acidity, and mineral deficiencies. Int. Crop Sci., 1: 371-9

Department of Food and Public Distribution (DoFPD). Department of Commerce (DoC); Directorate of Economics and Statistics (DES); Department of Agriculture and Cooperation (DoAC).

Deshmukh, P.B., Atale, S.B., Pandey, M.K., Vithare, D.G. and Golhar, S.R. 1999. Genetic divergence in durum wheat. Crop Improv., 26(1): 95-98.

Federer, W.T. 1956. Augmented Designs. Hawain Planters Record, 40: 191-207.

Gartnar, S.L., Tomer, Y.S. and Singh, V.P. 1989. Genetic divergence in early maturing pigeonpea. India J. Pulses Res., 2: 25-31.

Hailegiorgis, D., M. Mesfin and T. Genet, 2011. Genetic divergence analysis on some bread wheat genotypes grown in Ethiopia. J. Cent. Europ. Agric., 12(2): 344-352.

Hanson, G.H., Robinson, H.F., and Comstock, R.E. 1956. Biometrical studies of yield in screening populations of Korean Lesoedeza. Agron. J., 48: 268-272

Hoque, M., Rahman, L. 2006. Estimation of Euclidian distance for different morphophysilogical characters in some wild and cultivated rice genotypes (Oryza sativa L.). Pak. Sci., 1: 77- 79.

Iqubal, A., Khan, A.S., Khan, I.A., Awan, F.S., Ahmad, A. and Khan, A.A. 2007. Study of genetic divergence among wheat genotypes through random amplified polymorphic DNA. Genetics and Mol. Res., 6(3): 476-481.

Joshi, B.K., Mudwari, A., Bhatta, M.R. and Ferrara, G.O. 2004. Genetic diversity in Nepalese wheat cultivars based on agromorphological traits and coefficients of parentage. Nep. Agric. Res. J., 5: 7-17.

Katyal, J.C., Doshi, S.P. and Malhotra, P.K. 1985. Use of cluster analysis for classification of Benchmark soil samples from India in different micronutrient availability group. $J$. Agric. Sci. Combridge, 104: 421-424

Kumar, R., Prasad, B. K., M.K. Singh, Singh, G., and Verma, A. 2015. Genetic divergence analysis for morphophysiological traits, under timely and late sown condition in bread wheat (Triticum estivum L.). J. Wheat Res., 7(1): 27-30.

Mahalanobis, P.C. 1936. On the generalized distance in statistics. Proc. Natl. Inst. Sci., (India), 12: 49-55.

Mellingers, J.S. 1972. Measures of genetic similarity and genetic distance. Studies in genetics. VII Univ Tex. Publ., 27(13): $145-153$.

Mohammdi, S.A. and Prasanna, B.H. 2003. Analysis of genetic diversity in crop plant salient statistical tools and considerations. Crop sci., 43(4): 12351248.

Munns, R. 2005. Genes and salt tolerance: bringing them together. New Phytol., 167: 645-663.

Munns, R. and James, R.A. 2003 Screening methods for salinity tolerance: a case study with tetraploid wheat. Plant Soil, 253: 201-218

Rao, C.R. 1952. Advanced Statistical Methods in Biometric Research. John Wiley and Sons Inc., New York.

Roy, J.K., Lakshmikumaran, M.S., Balyan, H.S. and Gupta, P.K. 2004. AFLPbased genetic diversity and its comparison with diversity based on SSR, SAMPL and phenotypic traits in bread wheat. Biochemical Genetics, 42(1-2): 43-59.

Shwi, U.H., Murthy, B.R., Singh, H.B. and Rao, U.M.B. 1972. Genetic divergence 
in recent elite strains of soybean and groundnut in India. Indian J. Genet., 32(2): 285-298.

Singh, S.K., Singh, B.N., Singh, P.K. and Sharma, C.L. 2006. Genetic divergence of exotic germplasm lines in wheat ( $T$. aestivum L.). Indian J. Plant Genet. Res., 19(2): 218-220

Singh, D., Singh, S.K., Singh, K.N 2009. Diversity of Salt Resistance in a Large Germplasm Collection of Bread Wheat (Triticum aestivum L.). Crop Improvement, 36(1): 9-12.

Verma, A.K., Singh, P.K., Vishwakarma, S.R. and Tripathi, R.M. 2006. Genetic divergence in wheat ( $T$. aestivum $L$.), Farm Sci. J., 15(1): 32-34.

Zaman, M.R., Paul, D.N.R., Kabir, M.S., Mahbub, M.A.A., Bhuiya, M.A.A. 2005. Assessment of Character Contribution to the Divergence for some Rice Varieties. Asian J. Plant Sci., 4(4): 388-391.

Zubair, M., S.U. Ajmal, M. Anwar and M. Haqqani. 2007. Multivariate analysis for quantitative traits in mungbean [Vigna radiate (L.) Wilczek]. Pak. J. Bot., 39: 103-113.

\section{How to cite this article:}

Manoj Kumar Pandey, H.N. Bind, Sanjeev Kumar and Singh, B.N. 2017. Genetic Divergence in Wheat (Triticum aestivum L. Thell.) Under Saline Sodic Condition. Int.J.Curr.Microbiol.App.Sci. 6(5): 181-189. doi: http://dx.doi.org/10.20546/ijcmas.2017.605.021 